\title{
Hvordan få flere kvinner til å ta celleprøve?
}

Kvinner som får invitasjon til celleprøvetaking, har trolig større sannsynlighet for å ta celleprøve av livmorhalsen enn de som ikke får en slik invitasjon.

\section{Marita S. Fønhus}

Seniorforsker

Cochrane Norge og Nasjonal kompetansetjeneste for læring og mestring innen helse (NK $\mathrm{LMH}$ )

\section{Therese Kristine Dalsbø}

Seniorrådgiver

Cochrane Norge

Celleprøve livmorhalskreft

Livmorhalsprogrammet

Kreftregisteret

Sykepleien Forskning 202116 (87232) (e-87232)

DOI: 10.4220/Sykepleienf.2021.87232

Effekten ser ut til å være størst når en timeavtale ligger ved invitasjonen.

Andre typer tiltak som muligens kan få flere kvinner til å ta celleprøve (livmorhalsprøve), er opplæring og undervisning, men her er funnene mer usikre enn for funnene om invitasjon. Det viser en Cochraneoversikt.

\section{Hva sier forskningen?}

I systematiske oversikter samles og vurderes tilgjengelig forskning. I denne systematiske Cochraneoversikten var spørsmålet som følger: «Hvilke tiltak kan få flere kvinner til å ta celleprøver?» 
- invitasjoner trolig øker antallet kvinner som tar celleprøver, sammenliknet med vanlig oppfølging eller ingen invitasjoner.

- personlige invitasjoner muligens $\varnothing \mathrm{ker}$ antallet kvinner som tar celleprøver, sammenliknet med standard invitasjonsbrev.

- invitasjoner med timeavtale trolig $\varnothing$ ker antallet kvinner som tar celleprøver, sammenliknet med invitasjoner uten timeavtale.

\begin{tabular}{|c|c|c|c|}
\hline Hva skjer? & Invitasjon (alle typer invitasjoner) & $\begin{array}{l}\text { Ingen invitasjon eller } \\
\text { vanlig oppfølging }\end{array}$ & $\begin{array}{c}\text { Tillit til } \\
\text { resultatet }^{1}\end{array}$ \\
\hline \multirow{3}{*}{$\begin{array}{l}\text { Antallet kvinner som tar celleprøver } \\
\text { Invitasjoner øker trolig antallet kvinner som tar } \\
\text { celleprøver, sammenliknet med vanlig } \\
\text { oppfølging eller ingen invitasjon }\end{array}$} & 139 & 81 & \\
\hline & $\begin{array}{c}\text { per } 1000 \text { kvinner } \\
(121 \text { til 159)* }\end{array}$ & per 1000 kvinner & Middels \\
\hline & $\begin{array}{l}\text { Personlig invitasjon (ansikt til ansikt, } \\
\text { telefon eller målrettet brev) }\end{array}$ & $\begin{array}{l}\text { Standard } \\
\text { invitasjonsbrev }\end{array}$ & $\begin{array}{c}\text { Tillit til } \\
\text { resultatet }^{1}\end{array}$ \\
\hline \multirow{3}{*}{$\begin{array}{l}\text { Antallet kvinner som tar celleprøver } \\
\text { Personlige invitasjoner øker muligens antallet } \\
\text { kvinner som tar celleprøver, sammenliknet med } \\
\text { standard invitasjonsbrev }\end{array}$} & 142 & 108 & \\
\hline & $\begin{array}{l}\text { per } 1000 \text { kvinner } \\
(120 \text { til } 168)^{*}\end{array}$ & & Liten \\
\hline & Invitasjon med timeavtale & $\begin{array}{l}\text { Invitasjon uten } \\
\text { timeavtale }\end{array}$ & $\begin{array}{l}\text { Tillit til } \\
\text { resultatet }^{1}\end{array}$ \\
\hline \multirow{2}{*}{$\begin{array}{l}\text { Antallet kvinner som tar celleprøver } \\
\text { Invitasjoner med timeavtale øker trolig antallet } \\
\text { kvinner som tar celleprøver, sammenliknet med } \\
\text { invitasjoner uten timeavtale }\end{array}$} & 364 & 226 & \\
\hline & $\begin{array}{c}\text { per } 1000 \text { kvinner } \\
(335 \text { til } 396)^{*}\end{array}$ & per 1000 kvinner & Middels \\
\hline
\end{tabular}

\section{Bakgrunn}

Tall fra Verdens helseorganisasjon viser at livmorhalskreft er den fjerde vanligste kreftformen hos kvinner. Gjennom sine nye anbefalinger for screening og behandling av livmorhalskreft har de som målsetting at over 70 prosent tar livmorhalsprøve jevnlig. Arsaken til at de anbefaler jevnlige livmorhalsprøver, er å avdekke kreft tidlig og sikre at den behandles så tidlig som mulig. 
Tall fra Kreftregisteret viser at i Norge får over 300 norske kvinner livmorhalskreft årlig, og mellom 70 og 90 kvinner dør av dette. I Norge får kvinner mellom 25 og 69 år påminnelse fra Livmorhalsprogrammet når det er på tide å bestille celleprøve. Under pandemien har imidlertid deltakelsen falt til under 70 prosent $\mathrm{i}$ Norge.

\section{«Pandemien kan ha ført til at så mange som 55000 kvinner ikke tok livmorhalsprøve.»}

Pandemien kan ha ført til at så mange som 55000 kvinner ikke tok livmorhalsprøve. Oppdaterte tall viser at over 400 ooo kvinner i Norge ikke har fulgt anbefalingene om å sjekke seg jevnlig, og 200 ooo har ikke tatt livmorhalsprøve på ti år eller mer (Kreftregisteret).

\section{Hva er denne informasjonen basert på?}

Forfatterne av Cochrane-oversikten gjorde et $s \varnothing \mathrm{k} \mathrm{i}$ aktuelle forskningsdatabaser i juni 2020 og fant 70 randomiserte kontrollerte studier. De lagde metaanalyser fra 69 studier med til sammen 257899 kvinner. Metaanalysene, som omhandlet effekten av invitasjon, som er omtalt ovenfor, er basert på 24 studier og 141391 kvinner. 


\begin{tabular}{|c|c|c|}
\hline PICO & Hva lette de etter? & Hva fant de? \\
\hline Populasjon & Kvinner & $\begin{array}{l}\text { De fleste studiene tok utgangspunkt i alle kvinner, mens } 14 \text { av studiene var rettet } \\
\text { mot spesifikke målgrupper som hadde landbakgrunn fra Asia, Afrika eller Latin- } \\
\text { Amerika. }\end{array}$ \\
\hline $\begin{array}{l}\text { Tiltak og } \\
\text { sammenlikning }\end{array}$ & $\begin{array}{l}\text { Alle typer tiltak rettet direkte mot } \\
\text { kvinner som er aktuelle for } \\
\text { celleprøvetaking. } \\
\text { Kontrollsammenlikninger kunne } \\
\text { være ingen tiltak eller vanlig } \\
\text { oppfølging. }\end{array}$ & $\begin{array}{l}\text { Tiltakene ble gitt skriftlig eller muntlig, ansikt til ansikt eller per telefon, sms eller } \\
\text { e-post. } \\
\text { Noen tiltak var av enklere karakter, som påminnelse om å ta prøve, en konkret } \\
\text { timeavtale eller informasjon om prøven, mens andre var mer komplekse tiltak } \\
\text { som inkluderte rådgivning, utregning av risikofaktorer, tilrettelegging eller } \\
\text { økonomiske insentiver. }\end{array}$ \\
\hline Utfall & $\begin{array}{l}\text { - Celleprøvetaking (opptak av } \\
\text { celleprøvetaking/screening) } \\
\text { - Timeavtale } \\
\text { - Intensjoner om å ta celleprøve } \\
\text { - Holdninger til } \\
\text { celleprøvetaking/screening } \\
\text { - Kunnskap om } \\
\text { celleprøvetaking/screening } \\
\text { - Tilfredshet med tjenesten } \\
\text { - Kostnader }\end{array}$ & $\begin{array}{l}\text { Det var kun oppmerksomhet på utfallet celleprøvetaking i metaanalysene og i } \\
\text { resultattabellene. }\end{array}$ \\
\hline Setting & Alle land og alle helsesettinger & $\begin{array}{l}\text { Det var } 33 \text { studier fra USA, ti fra Australia, sju fra England, fire fra Sverige og } \\
\text { Canada, to i Frankrike og Malaysia, én fra Norge, Danmark, Sør-Afrika, Tyskland, } \\
\text { Spania og Kenva. De fleste studiene ble utførtt i primærhelsetienesten. }\end{array}$ \\
\hline Tillit til resultatet & De brukte GRADE & $\begin{array}{l}\text { Studiene de fant, hadde mangelfull rapportering med tanke på hvordan de ble } \\
\text { gjennomført. Dessuten var det stort frafall, og i de klynge-randomiserte studiene } \\
\text { var det skjevheter i utvalget allerede ved oppstarten av studiene. Det er derfor } \\
\text { noe redusert tillit til alle resultatene. For noen sammenlikninger har vi middels } \\
\text { tillit, mens andre har vi liten eller svært liten tillit til. }\end{array}$ \\
\hline
\end{tabular}

\section{Systematisk oversikt}

I systematiske oversikter søker man etter og oppsummerer studier som svarer på et konkret forskningsspørsmål. Studiene blir funnet, vurdert og oppsummert ved å bruke en systematisk og forhåndbeskrevet fremgangsmåte. (Les mer: $\underline{\text { Cochrane) }}$

\section{Tillit til resultatet (GRADE)}

Når vi oppsummerer studier og presenterer et resultat, er det viktig å si noe om hvor mye tillit vi kan ha til dette. Det handler om hvor trygge vi kan være på at resultatet gjenspeiler virkeligheten. GRADE er et system vi bruker for å kunne bedømme tilliten til resultatet. I GRADE vurderer vi blant annet:

- hvor godt studiene er gjennomført

- om studiene er store nok

- om studiene er like nok

- hvor relevante studiene er

- om alle relevante studier er fanget opp 


\section{Kilde}

Staley H, Shiraz A, Shreeve N, Bryant A, Martin-Hirsch PPL, Gajjar K. Interventions targeted at women to encourage the uptake of cervical screening. Cochrane Database of Systematic Reviews. 2021;

(9):art.nr.:CDoo2834.

DOI: 10.1002/14651858.CDoo2834.pub3

Les hele Cochrane-oversikten her: Interventions

targeted at women to encourage the uptake of cervical screening 